\title{
The Nanxun Legacy and China's Development in the Post-Deng Era
}


This page is intentionally left blank

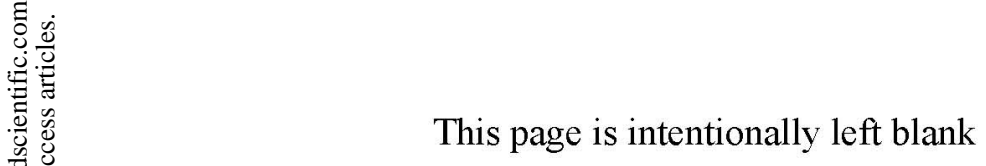




\title{
The Nanxun Legacy and China's Development in the Post-Deng Era
}

\author{
Edited by \\ JOHN WONG \& \\ ZHENG YONGNIAN
}

East Asian Institute

National University of Singapore 
(C) 2001 Singapore University Press

Yusof Ishak House, NUS

31 Lower Kent Ridge Road

Singapore 119078

and

World Scientific Publishing Co. Pte. Ltd.

PO Box 128, Farrer Road, Singapore 912805

USA office: Suite 1B, 1060 Main Street, River Edge, NJ 07661

UK office : 57 Shelton Street, Covent Garden, London WC2H 9HE

ISBN 9971-69-246-5 (Case)

All rights reserved. No part of this publication may be reproduced, stored in a retrieval system, or transmitted, in any form or by any means, electronic, electrical, chemical, mechanical, optical, photocopying, recording or otherwise, without the prior permission of the copyright holder.

Typeset and Printed by: Humanities Press 


\section{CONTENTS}

Editors and Contributors ix

\section{Part I Overview}

1. The Political Economy of China's

Post-Nanxun Development

John Wong and Zheng Yongnian

2. Deng Xiaoping's Nanxun in Perspective Michel Oksenberg

\section{Part II Economic Growth and Transformation}

3. The Economics of the Nanxun John Wong

4. China's Institution Development for a Market Economy since Deng Xiaoping's 1992 Nanxun Lu Ding

5. Deng Xiaoping's Nanxun: Impact on China's Regional Development Tian Xiaowen 


\section{Part III Social Dynamism and Consequences of Economic Transition}

6. Rural Cadres and the Market Economy in the

Deng Era: Evidence from a National Survey Andrew G. Walder

7. Income Inequality by Ethnicity in Urban China Zang Xiaowei

8. Employment Service and Unemployment Insurance 143 GuXin

\section{Part IV Ideological Decline, Party Decay, and Return to Control?}

9. Ideological Decline, the Rise of an Interest-based Social Order, and the Demise of Communism in China

Zheng Yongnian

10. Dream on: Communists of the Dengist Brand in Capitalistic China

Lance L. P. Gore

11. The Return of Ideology? Struggling to Organize Politics during Socio-economic Transitions Wu Guoguang

\section{Part V Legal Reforms and the Search for More Efficient Governance}

12. Liberation and Control: Deng Xiaoping's Nanxun Legacy and the Chinese Legal System Pitman B. Potter 
13. The Developments of Intellectual Property

Protection in China since Deng's Southern Tour Lo Vai Io

14. China's Constitutional Changes and

Deng Xiaoping's Legacy

Zou Keyuan

Index 
This page is intentionally left blank

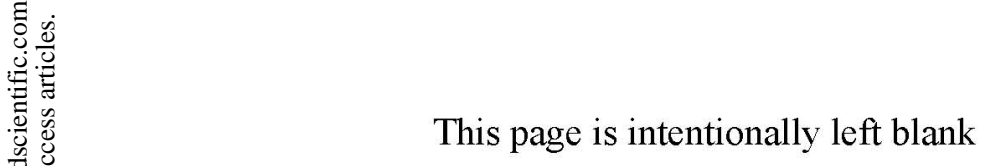




\section{EDITORS AND CONTRIBUTORS}

John Wong is Research Director of the East Asian Institute at the National University of Singapore. He was formerly Director of the Institute of East Asian Political Economy (1990-96). His publications include Land Reform in the People's Republic of China (1973), ASEAN Economies in Perspective (1979), The Political Economy of China's Changing Relations with Southeast Asia (1986), and Understanding China's Socialist Market Economy (1993), as well as numerous papers on the economic development of China, ASEAN, and the Asia NIEs. He also edited China's Political Economy, and China: Two Decades of Reform and Change (with Wang Gungwu, 1998, 1999).

Zheng Yongnian is Senior Research Fellow at the East Asian Institute of the National University of Singapore. He obtained his Ph.D. in politics from Princeton University. He was formerly a research fellow of SSRC/MacArthur Foundation of International Peace and Security at Harvard University. His articles have appeared in various academic journals such as Political Science Quarterly, Third World Quarterly, Asian Survey, Pacific Review and Asian Affairs. Zheng has published many books on China's domestic politics, and his latest book is Discovering Chinese Nationalism in China: Modernization, Identity, and International Relations (1999). He also edited Reform, Legitimacy and Dilemmas: China's Politics and Society (with Wang Gungwu, 2000).

Lance L. Gore is Assistant Professor at Bowdoin College (USA). He obtained his Ph.D. in political science from University of Washington, and was formerly a research fellow at the East Asian Institute of National University of Singapore. He received his academic training in the fields of comparative politics, international relations, political economy, and Chinese politics. His latest book is Market Communism: The Institutional Foundation of China's Post-Mao Hyper-Growth. 
Gu Xin is Post-doctoral Fellow at the Fairbank center for East Asian research, Harvard University, and Fellow at the Institute of Social Development and Public Policy, Beijing Normal University. He was also formerly a research fellow at the East Asian Institute of the National University of Singapore. He obtained his Ph.D. from Leiden University, the Netherlands. His articles have appeared in a dozen of international journals such as Economy and Society, Journal of Asian Studies, The China Quarterly, and The China Journal.

Lo Vai Io is Research Fellow at the East Asian Institute of the National University of Singapore. She obtained J.D. from Brigham Young University and Ph.D. from University of Washington. Her research has concentrated on Chinese, Japanese, and American Laws. Her latest publication is Law and Industrial Relations: China and Japan After World War II (Kluwer Law International, 1999).

Lu Ding obtained his $\mathrm{Ph} . \mathrm{D}$. in economics from Northwestern University in 1991. Teaching in Department of Economics, National University of Singapore, he is also affiliated with the university's East Asian Institute and Center for TeleMedia Strategy as Research Associate. Before he joined the NUS in 1992, Dr. Lu held various teaching or research positions at Fudan University (Shanghai), Illinois State Government, Northwestern University and University of Nebraska at Omaha. He has published 3 books, 12 book chapters, and 15 journal articles in areas of industrial economics, international trade and investment, money and banking, and transitional economies. Most of these publications have a focus on the Asia-Pacific region, including the Chinese economy in particular.

Michel Oksenberg is a Senior Fellow at the Asia/Pacific Research Center at Stanford University where he is also a Professor of Political Science. He obtained his B.A. from Swarthmore College (1960), and his M.A. (1963) and Ph.D. (1969) in political science from Columbia University. He was on the faculty of Stanford University (1966-68), Columbia University (1968-74), and the University of Michigan (1973-92) where he was also Director of the Center for Chinese Studies. From 1977 to 1980, he served as senior staff member of the National Security Council in Washington, DC, with special responsibility for China and Indonesia. He writes extensively on contemporary China and on American foreign policy toward the East Asia region. His books include, inter alia: China: The Convulsive Society (1971); Policy Making in China (1988); An Emerging China 
in a World of Interdependence (1994); A US Policy for the Changing Realities of East Asia (1996); Living with China (1997); and China Joins the World (1999).

Pitman B. Potter is Professor of Law and Director of Chinese Legal Studies at the University of British Columbia, Faculty of Law. He is also a consultant to the Vancouver law firm of Ladner Downs. He received his $\mathrm{Ph}$.D. from the University of Washington in political science. He practised law full time beginning in 1985, including a three-year posting in Beijing as a resident attorney. In addition to his current research and teaching activities, he continues to advise governments and private companies on Chinese affairs. His publications include Legitimation and Contract Autonomy in the PRC: The Contract Law of China (1992), Domestic Law Reforms in Post-Mao China (1994), and Foreign Business Law in China: Past Progress, Future Challenges (1995), as well as over thirty major articles and book chapters on Chinese law and politics.

Tian Xiaowen is Research Fellow at the East Asian Institute of the National University of Singapore. He obtained his Ph.D. from the Australian National University. His research interests have focused on economic reform and development in developing economies. He has published extensively on China's economic reforms and opendoor policy, SOE reforms, uneven regional developments, and growth dynamics. He has published numerous papers in various academic journals. His book, Dynamics of Development in An Opening Economy: China Since 1978, was published by Nova Science Publishers (1998).

Andrew G. Walder obtained his BA (Political Science) from the Johns Hopkins University in 1975 and Ph.D. (Sociology) from the University of Michigan in 1981. He taught in Columbia University, 1981-87. In 1987 he moved to Harvard University and in 1989 became professor of sociology there. During 1995-98 he was professor and dean, Division of Social Science, Hong Kong University of Science and Technology. Currently, he is professor of sociology in Stanford University. He has written extensively and published voluminously on China in academic journals including American Journal of Sociology and American Sociological Review. His influential book Communist Neo-Traditionalism: Work and Authority in Chinese Industry published in 1986 received the Distinguished Scholarly Publication Award and the European Group 
on Organizational Studies Award by the American Sociological Association, and the Joseph Levenson Prize by the Association for Asian Studies.

Wu Guoguang, currently an Assistant Professor in Department of Government and Public Administration at the Chinese University, obtained his Ph.D. in political science from Princeton University, and, in the 1980s, served as a speechwriter and a policy advisor on political reform to Zhao Ziyang, then Prime Minister of China and the General Secretary of the Chinese Communist Party. He also worked as an editorialist in the People's Daily in Beijing. In the United States, he was awarded several prestigious professional and academic fellowships, including Nieman Fellowship from Harvard University, Luce Fellowship from Columbia University, and An Wang Post-Doctoral Fellowship from Harvard University. He is author and co-author of 7 books and numerous articles on Chinese domestic politics and China's foreign relations. He has also published numerous papers in leading academic journals.

Zang Xiaowei obtained his Ph.D. in Sociology from University of California at Berkeley in 1992 and has published more than 20 book chapters and refereed journal articles on China, Australia and Singapore, including those in Western Sociological Perspectives on Post-Mao Chinese Society (Oxford University Press, 1999), Australia and New Zealand Journal of Sociology, The China Quarterly, International Migration, and Organization Studies. His book, Children of the Cultural Revolution: Family Life and Political Behavior in Mao's China, was published by Westview Press in 1999.

Zou Keyuan is Research Fellow in the East Asian Institute of the National University of Singapore. He obtained his Ph.D. from Beijing University. Before he joined the Institute, he taught and did research in Dalhousie University, Canada; Peking University, China, and Hannover University, Germany. He is a specialist in law, particularly international law. He has published numerous papers in various journals such as Asian Yearbook of International Law, Asia-Pacific Journal of Environment Law, Ocean Development and International Law, International Journal of Marine and Coastal Law, and Marine Policy. 